\title{
HOW DO GEOGRAPHY TEXTBOOKS DEAL WITH MAP SKILLS? A COMPARISON OF TURKEY AND ENGLAND
}

\author{
EYÜP ARTVİNLİ \\ Eskisehir Osmangazi University, Faculty of Education, Eskisehir, Turkey, e-mail: eartvinli@ogu.edu.tr
}

\section{LEYLA DÖNMEZ}

Eskisehir Osmangazi University, Faculty of Education, Eskisehir, Turkey, e-mail: leyladonmezogu@gmail.com

(Received: July 2020; in revised form: August 2020)

\begin{abstract}
The skills used in all areas and stages of education are important also in geographical education. The concept of skill is important for the individual's life at all stages of Education. Geographical skills contribute to the ability of individuals to think critically and solve problems. They also enable the individual to think at a metacognitive level. In this study, it was aimed to show the degree to which secondary geography textbooks gain the level of use of map skills. Maps are communication tools that show where and how positional information is found. One of the most important materials to be used in geographical education are Maps. The map, which will appeal to the student, should benefit the individuals in their daily life by an inductive method. Individuals with map skills can transfer this directly into their lives. They can both read the immediate environment in which they live and have global mapping skills and position analysis skills. In this study, skills, geographical skills, geography textbooks were analysed to determine their conceptual framework by focusing on map usage skills. This research is a qualitative one, with research data of 9, 10, 11 and 12 grade textbooks printed for the 2017-2018 to 2019-2020 academic years. The process of collecting and analyzing geography textbooks used the document review technique.
\end{abstract}

Keywords: maps, geographical skills, textbooks, geographical education

\section{NTRODUCTI ON}

Using maps literally is an important stage in teaching the science of geography. In geography, a narrative without a map causes students to have difficulty understanding subjects and leads them to memorization. Therefore, maps play a major role in understanding and learning geography subjects. In geographical education and training, it is important to prepare 
maps that play a role in the first degree, as well as to read them (Kızılçaoğlu, 2007). This issue is of great importance, as the ability to read maps is also involved in the acquisition of geographical skills. Unfortunately, although maps and map information in existing national education textbooks and most atlases available on the market are not suitable for use in geography education, they are also neither prepared, nor controlled by experts. But on the other hand Aksoy (2019, p. 599) found that the map skills are the important components of map literacy.

The materials that will be used in the teaching of the geography course are important because it is possible to carry every natural and human event to the classroom. For this reason, materials and teaching techniques need to be produced:

\footnotetext{
"Many topics, events, or areas described in geography courses are not possible to see on-site. Therefore, it is also difficult to teach and learn them. For this reason, it is very important to bring information about the subject or region to the course environment visually in geography courses. This is only possible with the help of course tools and equipment" (Şahin, 2001, p. 64).
}

Literally learning and using maps, which are materials of geography, is an important stage in teaching the science of geography. For this reason, maps play a major role in understanding and learning geography subjects. Each correctly designed map, in addition to its easy readability, is also effective in gaining geographical skills. Maps that will be used in the geography course must be prepared correctly:

"In geographical education and teaching, it is important to prepare maps that play a role in the first degree as well as to read them. The better the maps are prepared, the better the geography is explained. The more accurate the maps are used, the better the geography is understood" (Ünlü, Üçışık \& Özey, 2002, p.9).

In order to perceive the importance of geography, it is first necessary to be able to accurately define geography. Geography examines the interaction between the environment and humans, the living environment of human with the natural environment, human and economic activities within the framework of its own rules and principles and reveals its results (Şahin, 2001). A narrative made without the use of a map in geography courses leads students to not fully understand the subjects and turn to memorization (Kızılçaoğlu, 2007). Therefore, it can be mentioned using maps for spatial thinking, visualization, calculating the horizontal distance between two points on the Earth, showing the distribution, making comparisons, and also using maps as measurement and evaluation tools. After correctly defining geography, it is time to make sense of geographical skills.

In order to enable students, acquire geographical skills, in addition to interrogation skills, basic skills that include various methods related to geography and maps are also needed. In parallel with the study "Geography for Life: American National Geography Standards Project, 1994" (Geography for life: National Geography Standards Project, 1994), Gersmehl (1995, p. 97) divided geographical skills into two main sections. He evaluated the first as general skills, which are skills that other branches of science also benefit from, and the second as special skills (geographical skills) that make a very 
important contribution to the science of geography. In order for geography courses to be functional and in connection with real life, the core skills that will be taught to contribute to students' problem-solving skills are also vital.

According to Gersmehl, "the interrogation skills listed above are common skills. Hart and Dunbar conducted studies that were considered more geographical skills, and the 'list of skills' that could be used in teaching geography was determined by five titles" $(2005$, p. 97) Harte and Dunbar's work appears to conform to the geographical skills and logic set out in Geography for Life (National Geography Standards, 1994, pp. 41-44):

"1. Techniques related to geography or used in geography, 2. Map skills, 3. Data collection, 4. Data processing or computing process, 5. Data information. The skills discussed here focus on geography-related techniques and map-related skills needed to understand many types of data" (Harte \& Dunbar, 1994, p. 1).

In geographical education, it is possible to gain high-level cognitive skills such as analysis, synthesis, evaluation, critical thinking, and decisionmaking, but by including and applying various skills that are a prerequisite for each other in the curriculum. In some studies, it can be seen that if the students are forced to be active both in tools and in the field to engage map skills, they can have a great experience about elaborating the maps Dulamă, Ilovan \& Niţoaia, 2016). Harte and Dunbar explain this: "in all school programs, skills are characterized as very important and special elements. Geography curricula are also different and special compared to other programs in terms of skill acquisition. Because in geography, it is necessary to apply and develop a very wide range of skills in order to observe, keep records, comment, analyze, synthesize, and make informed decisions about various databases. These skills also include how information can be collected, through which processes it is to be passed, how to process it, how to present it, and how to best interpret it" (Harte \& Dunbar, 1994, p. 1). At this point, it is important how geographical skills should be understood and how they should be used at the metacognitive level.

According to Bednarz (1994), geography for life in the American National Geographic Standards Project, the geographic skills and the importance of geographic skills are mentioned. Individuals who learn geographical skills in critical periods become individuals who are critical, learn to live in harmony with real life, and can think both locally and globally:

"Geographic skills provide us with the most necessary tools and techniques for thinking geographically. These tools and techniques are the basis for a different approach or geographical point of view of geography in understanding physical and human activities and processes on earth. We use geographical skills to make decisions about our lives. Where to buy or rent a house, where to find a job, how to get to work or friends' homes, where to shop, where to go on vacation or to school. All these decisions require planning and the ability to use the geographic information system. Daily decisions and social activities are associated with each other in order to be able to think systematically about the environment and social issues. Social decisions are about air, water, soil pollution or local issues. For example, issues such as where to set up industrial facilities, schools and housing, how 
close or far away from agricultural areas will be industrial activities, also require the use of the geographic information system and the ability to have this. Business and management decisions; selection of the best location for a supermarket or regional airport, use of resources, or international trade include analysis of geographic information" (National Geography Standards, 1994, p. 41).

By accessing this information, the individual will have learned better what to do, how to do it, and what problem-solving methods to use. In this way, his/her sensitivity and responsibility for both his/her immediate environ ment and the stage in which he/she lives will increase at the same rate.

Map studies and map skills are one of the main skills of geographical education. Indeed, geography comes to mind when it comes to maps, both inside and outside the educational world. But if this thought means using the map, reading and analyzing it, it has found its meaning exactly.

Individuals who have acquired map skills have no difficulty in assuming important roles for themselves and their environment. Because the events we experience take place within a certain environment. The more a person understands the immediate environment in which they live, the easier they can perceive and analyze spatial information. An individual who has gained map skills has no difficulty creating mind maps. Thus, a geographical consciousness will be acquired (Bahar, Sayar \& Başıbüyük, 2010). Geographical awareness is necessary to individuals during critical periods.

A lot of work has been done on geographical skills. But the vast majority is not directly related to the geography lesson. In terms of contributing to the literature, these are also mentioned in this study. In the sample of primary school students, map skills were examined in the discipline of social studies (Ablak, Aksoy, 2018; Üzümcü, 2007; Ertuğrul, 2008; Sönmez, 2010; Kuzey, 2016; Abbak, 2016; Aksoy, Ablak, 2019). In these studies, it was found that students had low ability to calculate length and area. Research has been conducted in which map skills of teacher candidates in various branches have been identified. In these studies (Duman \& Girgin, 2007; Meriç, 2011; Balcl, 2015; Cendek, 2015; Özcan, 2015; Güneş, 2016) compared to other branches, geography and social studies teacher candidates had higher levels of map skills.

There are also studies in which map skills of secondary school students are determined in geography courses (Koc, 2008; Yurdam, 2013; Kartal, 2016). However, in these studies, only the current situation was determined. There are a limited number of studies in the field in which the program is designed and its effects tested in geography teaching. There are a limited number of studies in the field of geography teaching in which programs are designed and effects tested (Umek, 2003; Manzella, 2007; Petty \& Rule, 2008). There are also some but less studies about developing map skills of students at the university level (Dulamă \& Ilovan, 2016; Dulamă, 2014; Dulamă, Ilovan, \& Niţoaia, 2016).

Even in some undergraduate and master's degree student activites, it has been seen that students' cause of mistakes occurred in elaborating the 
HOW DO GEOGRAPHY TEXTBOOKS DEAL WITH MAP SKILLS? A COMPARISON ...

tourist street plans. Some of the causes are related to the curriculum in secondary education and refer to the first-year students at cartography specialization: lack of high school drawing classes, no habit to follow rules or procedures (Osaci-Costache et al., 2013, p. 105).

For these reasons, it is believed that this study will contribute to the field.

\section{METHODOLOGY}

In this section, the research method, study group, data collection tool and its application and the techniques used in data processing and analysis are discussed.

This research is a study according to the qualitative pattern:

"Qualitative research can be defined as research in which qualitative data collection methods such as observation, interview and document analysis are used and a process is followed for the realistic and holistic presentation of perceptions and events in a natural environment" (Yıldırım \& Şimşek, 2016, p. 45).

Research data was obtained through document analysis, which is one of the qualitative research methods, covering the analysis of written materials containing information about facts and events (Wachter, 2010). In this study, the level of map use in Geography textbooks was examined by content analysis. In content analysis, the purpose is to define the document and the message in the document within a system.

In this research, criteria sampling method was used from purposeful sampling methods. The logic and power of purposeful sampling lie in selecting information-rich cases for in depth study:

"Information-rich cases are those from which one can learn a great deal about issues of central importance to the purpose of the inquiry, thus the term purposeful sampling. Studying information-rich cases yields insights and in-depth understanding rather than empirical generalizations" (Patton, 2015, p. 264).

Geography textbooks published between 2017-2018 and 2019-2020 academic years were used as the sources of the data in the study. Turkish (published by the Ministry of National Education [MoNE]) and English geography textbooks were compared for their map usage levels.

Document analysis is a qualitative research method used to analyze the content of written documents rigorously and systematically (Wach, 2013). It is a systematic method used to examine and evaluate all documents, including printed and electronic materials. Like other analytical methods in qualitative research, document analysis requires that data be examined and interpreted in order to elicit meaning, gain understanding, and develop empirical knowledge (Corbin \& Strauss, 2008). In this study, geography textbooks which map skills included were used as the sources of the data. At the same time, the United Kingdom geography textbooks were important in terms of comparison with Turkish geography textbooks. 


\section{RESULTS}

In this section, the research results were determined according to the skill levels of using maps. Textbooks used in Turkey and United Kingdom were analysed according to usage level and the way maps develop students' map skills. The following results were reached, supported by images. The Geography curriculum in Turkey contrary to the previous one, is processbased instead of outcome-based, that is, it has a skill-education-based approach. In order to get this result, eight geographical skills have been identified in the Turkish geography curriculum: "This is one of the most significant properties of the high school geography education program compared to the previous one" (Artvinli, 2009, p. 51).

A skill-based structure is applied within the geography teaching program. Therefore, the acquisitions in geography lessons are to detect and organize the contents of activities, which will enable students to have these skills. Teaching geographical skills is also important for geography education to be applicable. According to the purpose of the geography lesson, individuals should also acquire geographical skills:

\footnotetext{
"In other words, the goal of geography education is not to convey content of acquisitions through activities, but to enable students to own geographical skills by organizing activities in the light of acquisitions. That is, acquisitions are not a goal but a tool for enabling students to have geographical skills" (Artvinli, 2010, p. 188).
}

Understanding geographical skills actually means understanding what geography wants to say:

"Thanks to geographical skills, the students become geographical knowledge equipped citizens" (Naylor \& Diem, 2001, p. 204).

Individuals equipped with geographical skills are also trained as effective citizens who know their rights and responsibilities.

Looking at the work done on map skills in Turkey, it can be found easily that map skills are ignored in Turkish geographical education. For example, Sönmez and Aksoy (2012, pp. 1905-1924) stated in their study, entitled "Determination of Map Usage Levels of Primary Education Second Level Students," that the map skills in the curriculum were insufficient. In another study by the same authors, titled "Map skills in primary education programs from republic to today," they stated that the content of maps should be enriched (Sönmez \& Aksoy, 2013, pp. 269-288).

In this study, images aiming to show the level of map-using skills were analysed primarily in geography textbooks belonging to the United Kingdom (Figures 1-8). Looking at the United Kingdom geography textbooks, it was concluded that each subject begins with a map and the map is related to other images, and the principle of integrity has a priority in these figures (Figures 1 and 2). 


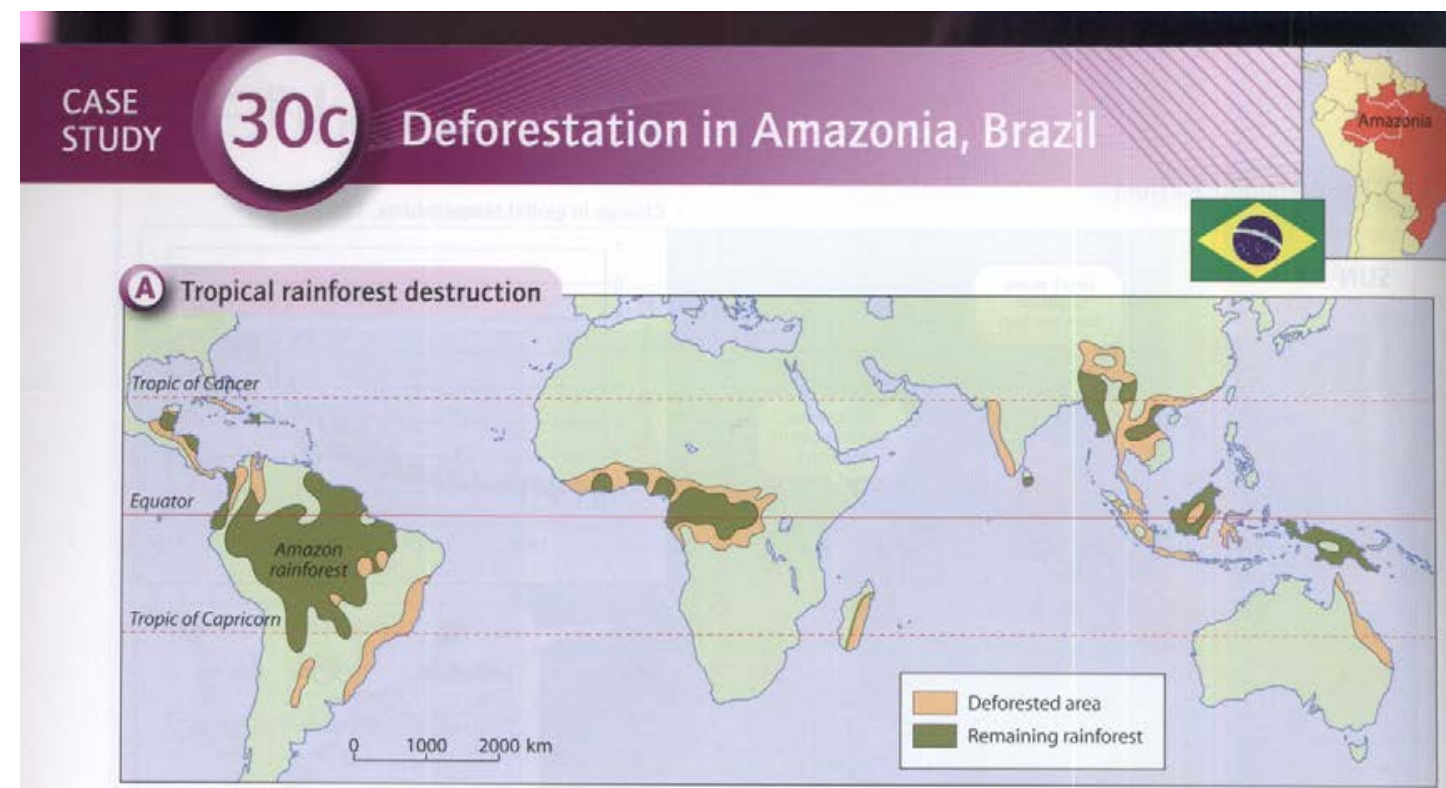

\section{What is deforestation?}

Throughout the tropics, rainforests are being cut down. This is known as 'deforestation'. Many people are worried about the destruction of tropical rainforests. Beautiful areas of natural vegetation and wildlife are being lost. Deforestation is also causing the extinction of many species and affects the global climate. If deforestation continues at the current rate, the world's rainforests will be gone within 100 years.

\section{Why does deforestation happen?}

Commercial logging - the cutting of trees for sale for timber or pulp - is the most common reason for deforestation. Commercial logging uses heavy machinery, such as bulldozers, road graders, and log skidders, to remove cut trees and build roads.

Large areas of rainforest are also cleared for agricultural use such as grazing animals and planting crops. Poor subsistence farmers chop down a small area and burn the tree trunks. a process called 'slash and burn'. Commercial agriculture occurs on a much larger scale, for growing crops and grazing animals. Large cattle pastures often replace rainforests to raise beef for the world market, and food crops are grown on plantations.

There are other ways in which deforestation

happens, e.g. building settlements and

industries, the construction of dams and mining for natural resources.

162 Cambridge IGCSE Geography

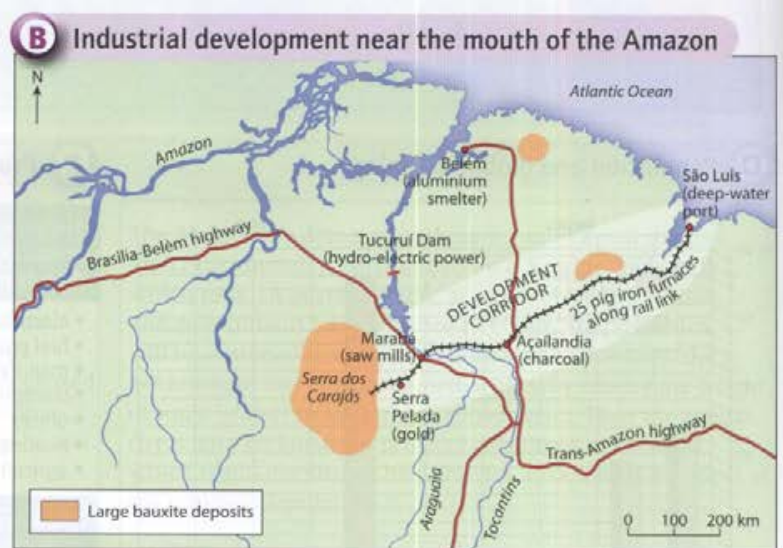

\section{Task 1}

Study Sources A and B and an atlas.

a Identify:

- the continent with the largest area of remaining rainforest

- a country in Africa where there are large areas of deforestation

b Estimate the percentage of the world's rainforest that has already been deforested.

c Draw a spider diagram showing some causes of deforestation in Amazonia.

Fig. 1. Using maps and integrating them with text and task in a UK geography textbook

(Cambers \& Sibley, 2010, p. 162) 


\section{Deforestation rates in Amazonia}

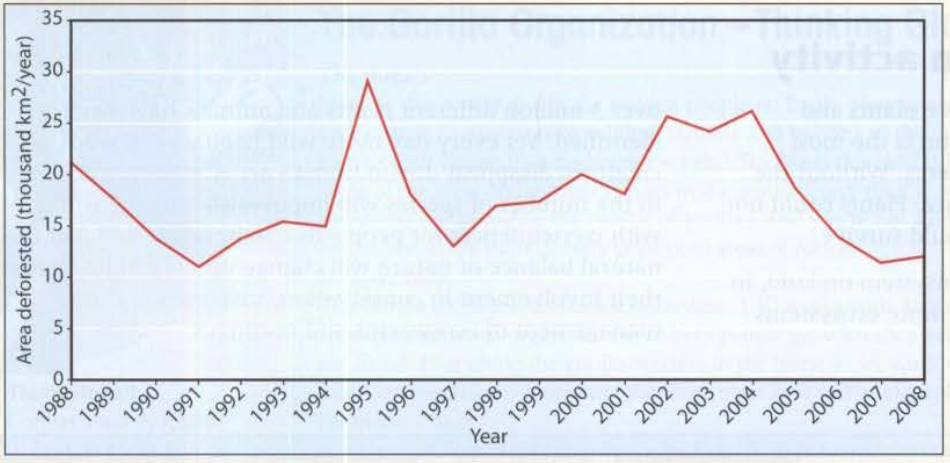

How deforestation affects the natural environment

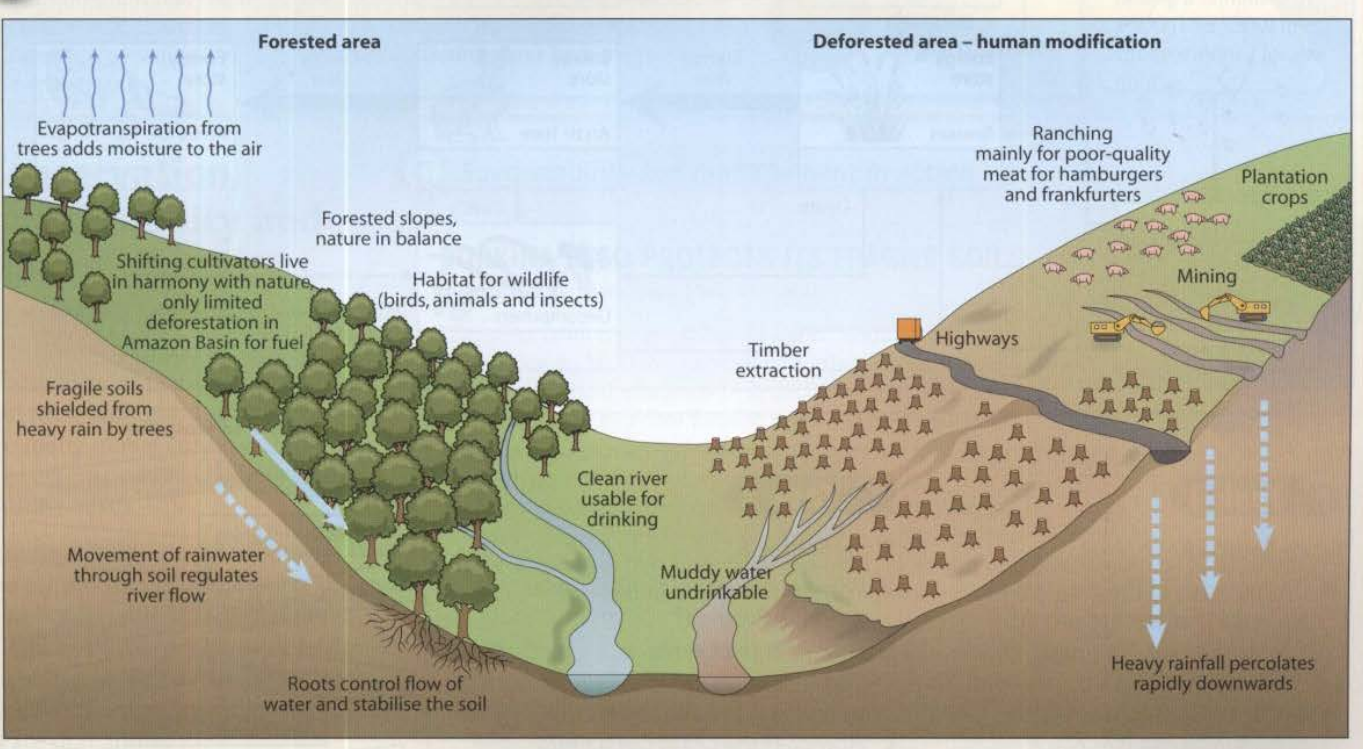

Task 2

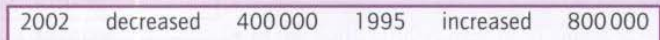

Study Source C.

Copy the following sentences. Fill in the missing words or figures from the list above.

In Amazonia in 1988 over $\mathrm{km}^{2}$ were deforested. Between 1988 and 2007 the amount of deforestation The amount between 1997 and

2004 then__ between 2004 and 2007. The largest area, $29000 \mathrm{~km}^{2}$, was lost in _ and the smallest amount, $10000 \mathrm{~km}^{2}$, was lost in __. In total between 1988 and $2007 \quad \mathrm{~km}^{2}$ have been deforested.

\section{Task 3}

Study Source D.

Describe the impacts

of deforestation on the

natural environment. Use

the Internet to find out

more information to add.

Fig. 2. The case of integrity and visualization in a UK textbook (Cambers \& Sibley, 2010, p. 163)

In the United Kingdom geography textbooks, the image of distribution is supported by text under the map instead of writing the names onto the 
HOW DO GEOGRAPHY TEXTBOOKS DEAL WITH MAP SKILLS? A COMPARISON ...

map, compelling students to compare them and create their own images (Figure 3).

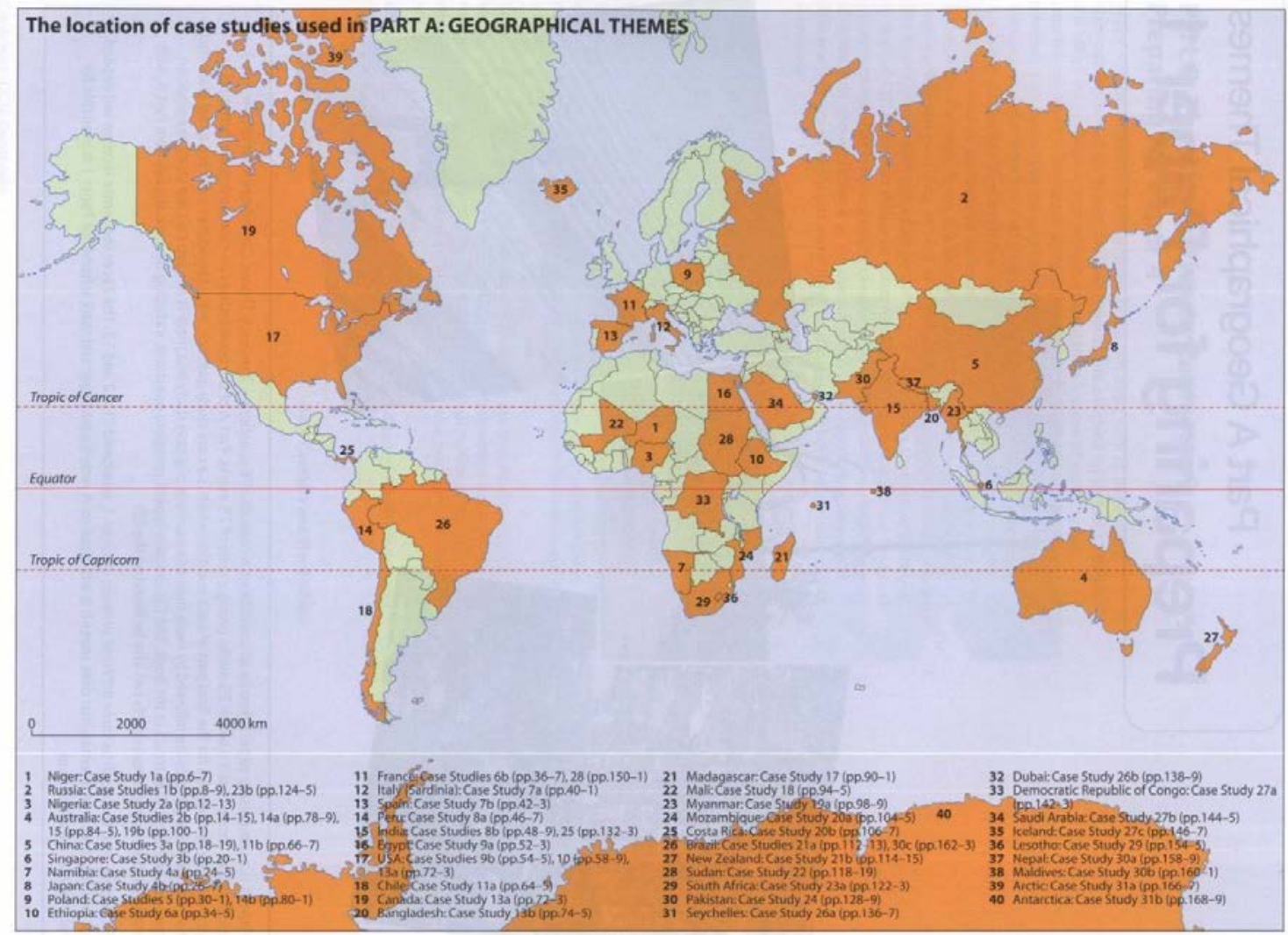

Fig. 3. The image of distrubition in a map within a UK textbook (Cambers \& Sibley, 2010, p. 2)

The maps shown in the UK geography textbooks are functional, while the task sections are both real-life and practical. This gives students the opportunity to access higher order thinking skills (Figure 4). 


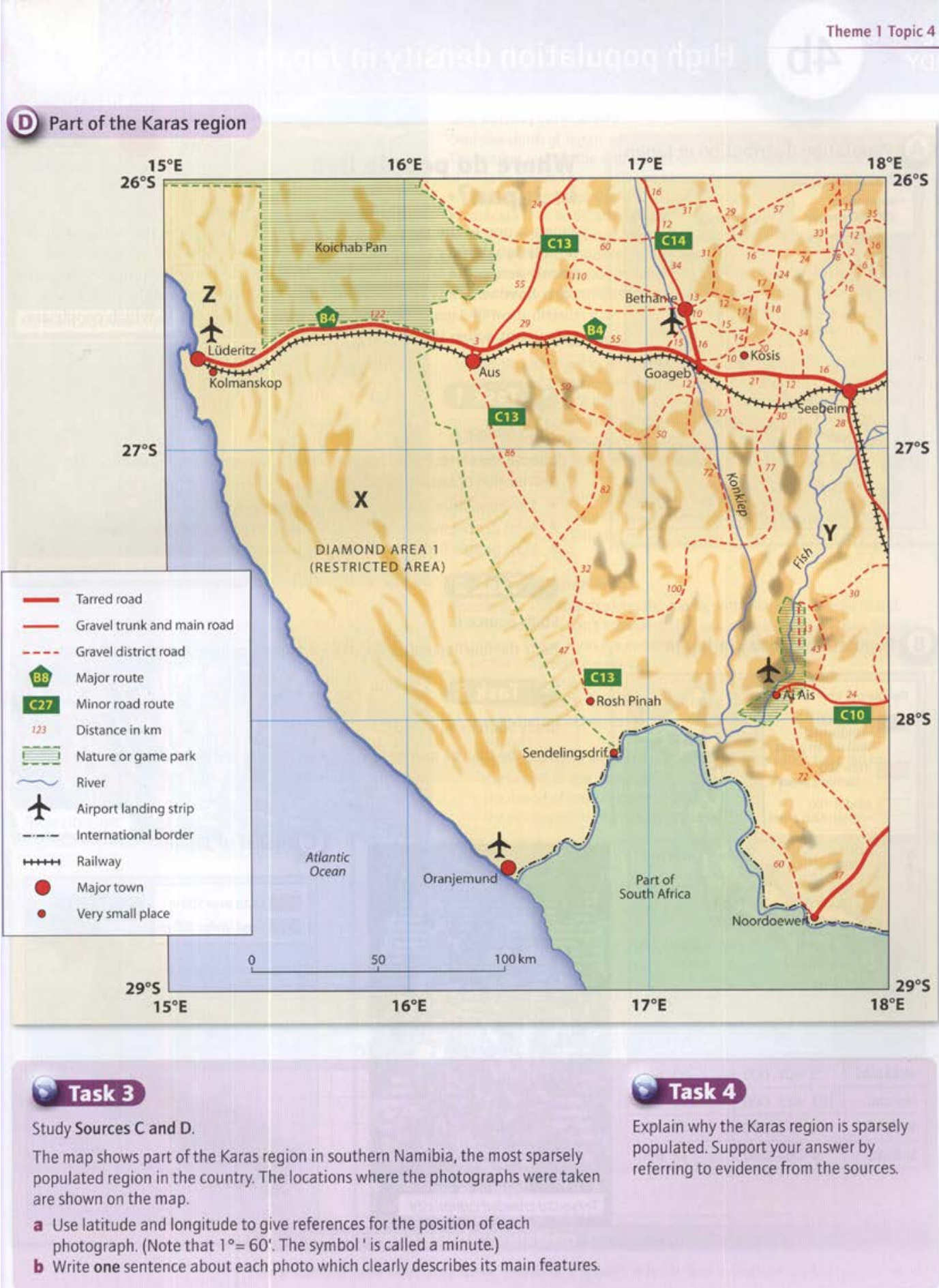

Fig. 4. Balance between map and activity tasks in a UK textbook (Cambers \& Sibley, 2010, p. 25) 
The maps shown in the United Kingdom geography textbooks are not only realistic, but also up-to-date. Maps are not only given at the level of knowledge, but also appeal to the students with images that develop students' mind map about change and continuity. Although the student does not go to that country or that city, he of she can deduce the existen ce and living conditions of a person there (Figure 5 ).

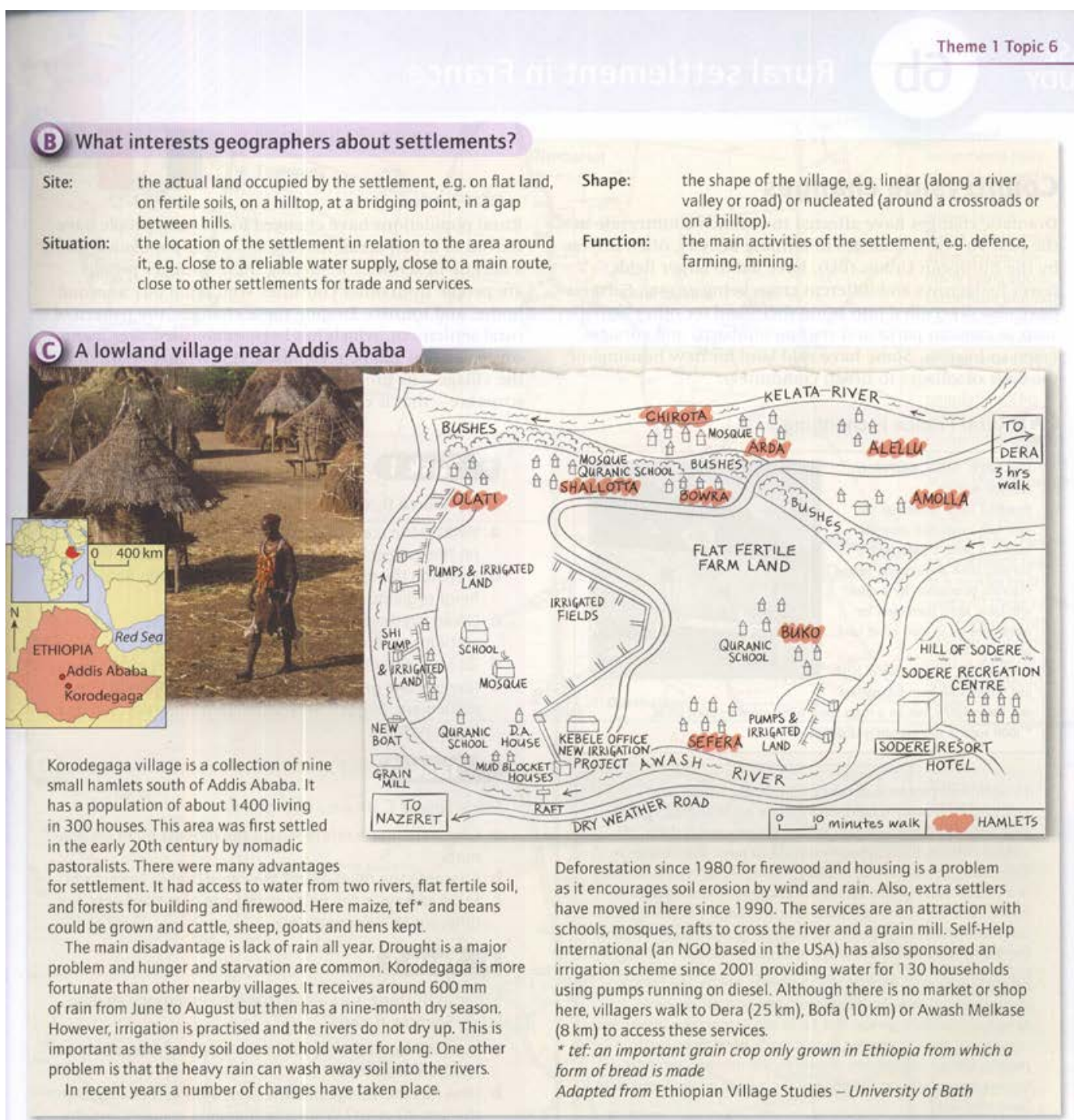

\section{Task 2}

Study Source C.

a Describe the location of the village in relation to Addis Ababa.

b Describe the site and function of this village

c Give three advantages for the villagers of this location.

d How have problems caused by the dry season been overcome?

e How has the village changed in the last 30 years?

f What part has Self-Help International played in changing the village?

\section{Task 3}

Self Help International (SHI) is advertising for an 18-year-old student to spend a 'gap year' helping people in villages like Korodegaga. The job is voluntary but all expenses are paid.

a Suggest different ways in which SHI could advertise the post.

b Choose one way and create the job advert.

Fig. 5. Using maps to develop students' mind map about change and continuity in a UK textbook

(Cambers \& Sibley, 2010, p. 35) 
When we look at the geography textbooks used in the UK, the maps that reflect the city planning and the tasks given at the end of the page show a structure at a metacognitive level, when evaluated according to Bloom's taxonomy. At the same time, it helps to develop the student's knowledge level by asking the student to produce new information (Figure 6).

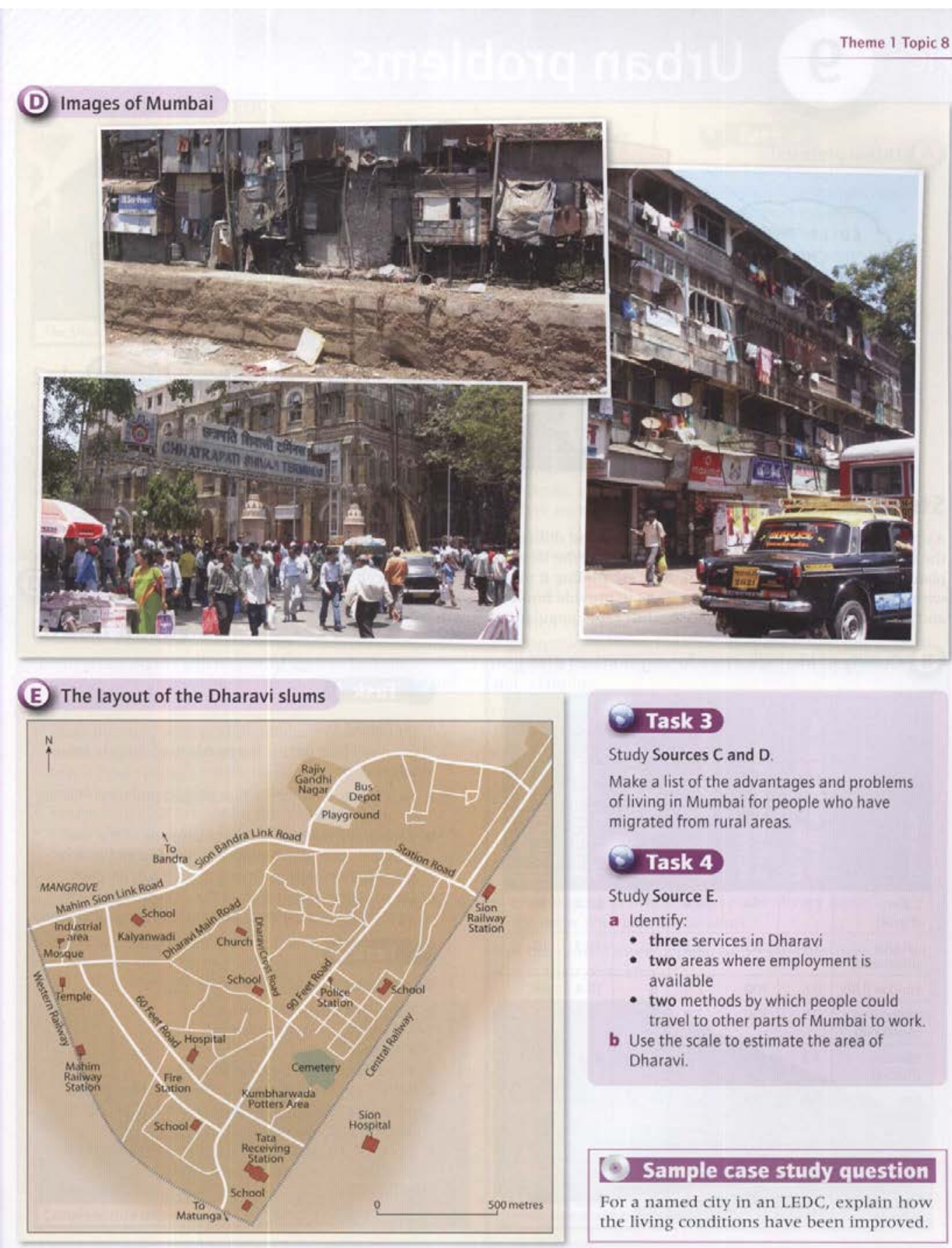

Fig. 6. Using maps and tasks in UK textbook to develop students' skills (Cambers \& Sibley, 2010, p. 49) 
HOW DO GEOGRAPHY TEXTBOOKS DEAL WITH MAP SKILLS? A COMPARISON ...

When reading a map in a textbook, the students do not see just a map in a UK textbook. Students also can find about reading and tables, diagrams and graphs about the same maps. The legend is not only the language of the map, but also the source that will help bring the student to the upper cognitive level skills. In this way, students are encouraged to work like in the field, by comparing the real image of the field and its map via tasks given in the activity (Figures 7 and 8 ).

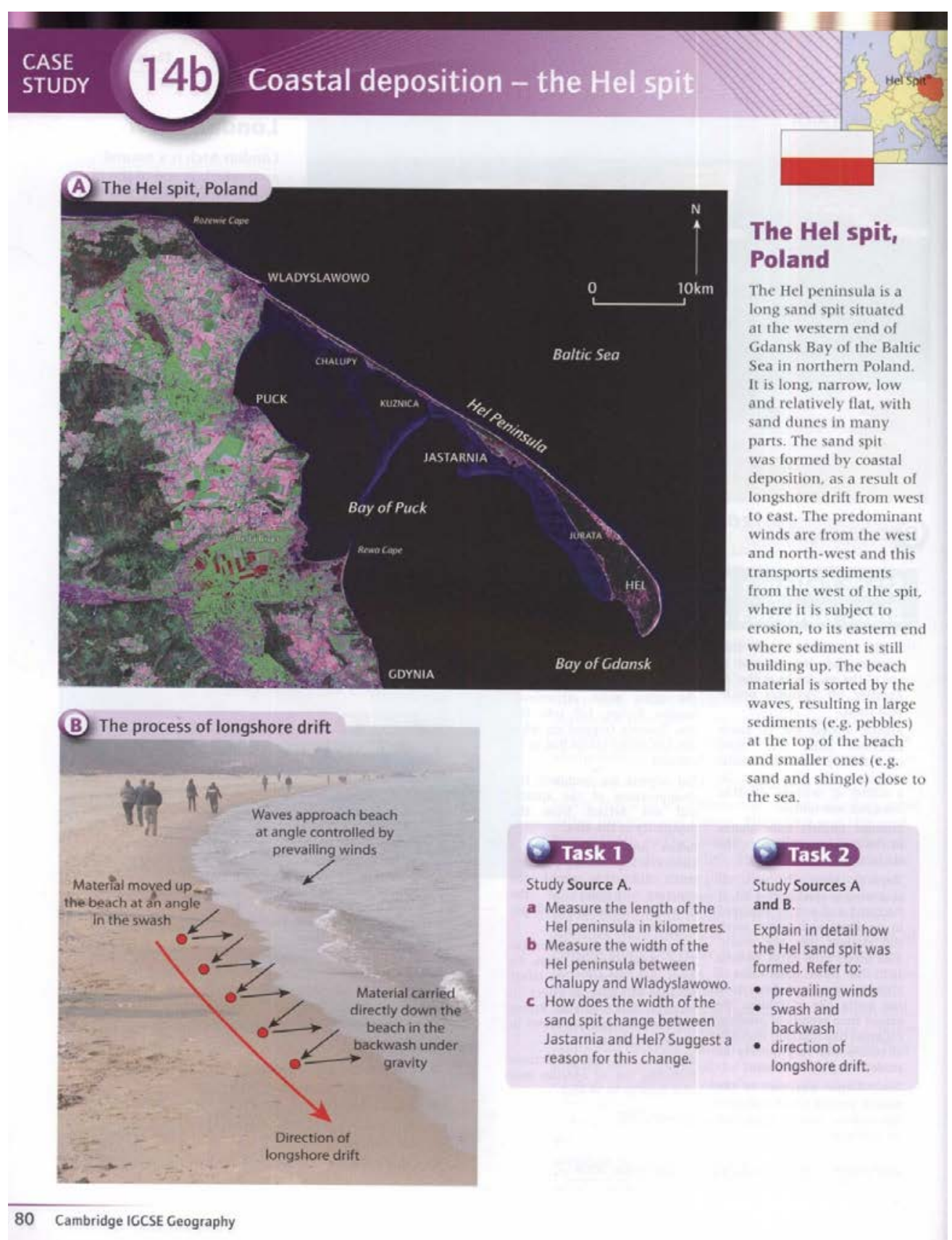

Fig. 7. Relationship between map, text, photograph and tasks: A holistic approach to visuality in a UK textbook

(Cambers \& Sibley, 2010, p. 80) 


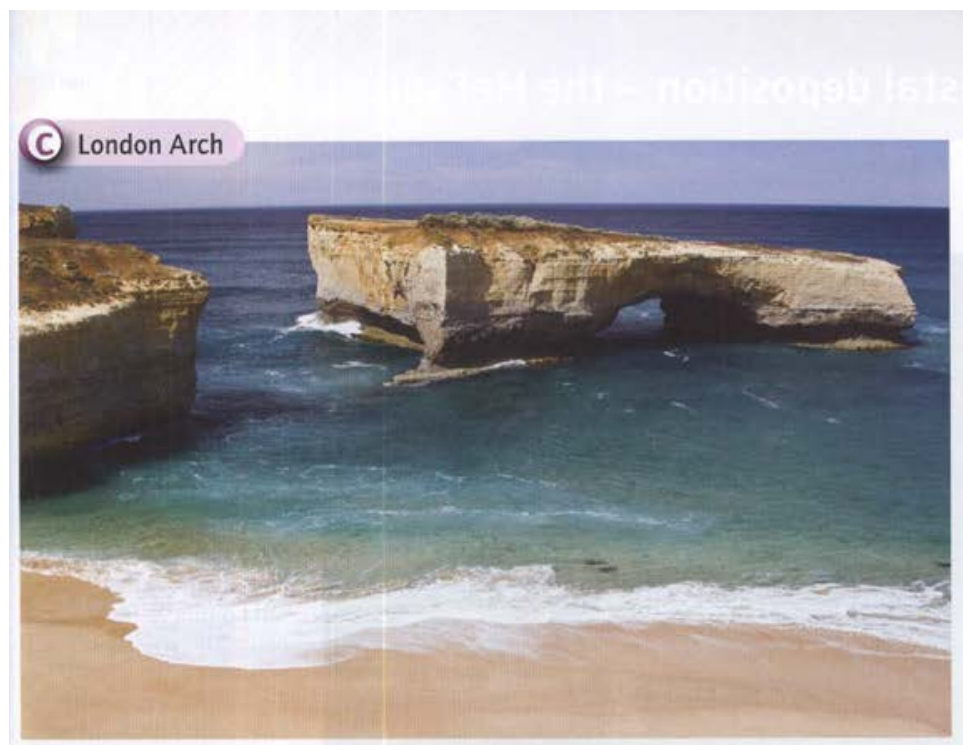

\section{Collapsing stacks}

\section{Stack Collapse Leaves Eight Apostles Standing}

A pile of rubble is all that But it leaves only 8 of the 12 remains after the collapse of apostles still standing.

one of the sea stacks at the '12 Just 15 years ago another of Apostles' off Victoria's south- the site's main attractions, west coast.

Around 9:00am the 50 metre limestone pillar that metre off Victoria's south-west const crumbled into the water. In a matter of seconds, all that remained was rubble.

Stunned tourists took photos of the dramatic change in the landscape.

Reports were it sort of shimmied or shuddered a bit, it fractured and sort of imploded in on itself and pretty much slid straight into the ocean: Alex Green from Parks Victoria said. 'So we've gone from a 50-metre sea stack down to a ten metre pile of rubble. We expect from reports of previous collapses like this that that pile of rubble will very quickly be eroded away by the ocean!

The collapse was part of the natural process that has shaped the popular tourist attraction for centuries.

STOPPRESS Only 7 stacks left in attractions,

Lndon Bridge, fell into the

sea. Tounsts trapped on what

was left of the bridge had to be will not detract from the popularity of the area.

Before and after photos of London Bridge already generate much discussion about the constant changes to the coastline and the latest collapse is another talking point.

Victorian Tourism Minister John Pandazopoulos says he does not expect the latest collapse vill have the collapse will have an effect on foll dow. Since London Bridge thell down tounism has grown in the region, he said.

Numerous ads and promotions featuring the 12 apostles may now have to be re-shot.

20 May 2007

September 2009
But experts are confident the disappearance of the apostle

\section{London Arch}

London Arch is a natural arch which is one of the main tourist attractions in the Port Campbell National Park. It was formed by the processes of coastal erosion, and until 1990 formed a complete doublespan natural bridge. The arch closest to the shoreline collapsed unexpectedly on 15 January 1990, leaving two tourists stranded on the outer part. They had to be rescued by helicopter. Before the collapse, the arch was known as London Bridge because of its similarity to the bridge over the river Thames in London, UK.

STOP PRESS Only 7 stacksieft... September 2009 o

\section{Task 3}

Study Sources C and D.

a The photograph shows what London Arch now looks like. Draw a labelled sketch to show what you think the feature was like before the collapse.

b Use geographical terminology to explain why one of The Twelve Apostles collapsed.

\section{Task 4}

There are many other famous arches and stacks. Here are some examples.

\begin{tabular}{|l|l|}
\hline Stacks: & Arches: \\
\hline Goat Rock, USA & Percé Rock, Canada \\
Old Harry Rocks, England & Holei Arch, Hawaii \\
The Needles, England & Durdle Door, England \\
Old Man of Hoy, Scotland & Porte d'Amante, France \\
Hopewell Rocks, Canada & Great Pollet Arch, Ireland \\
Po Pin Chau, Hong Kong & \\
Needle of Arsene Lupin, France & \\
Lange Anna, Germany & \\
\hline
\end{tabular}

Carry out research in groups and prepare a presentation, perhaps using PowerPoint. In your presentation you need to choose one stack and one arch from the list, or an example from your own country.

a Describe the precise location of your chosen stack and arch and show them on a map.

b Find photographs to show your chosen stack and arch and describe their main features (e.g. shape, size, rock type).

c Explain clearly how each of the features was formed.

Fig. 8. Using maps to answer the tasks in a UK textbook

(Cambers \& Sibley, 2010, p. 79) 
HOW DO GEOGRAPHY TEXTBOOKS DEAL WITH MAP SKILLS? A COMPARISON ...

Images that reflect the level of map-using skills of geography textbooks in Turkey have been highlighted with the following figures (Figures 9, 10, 11). It has been determined that geography textbooks used in Turkey are started primarily with a history (Figure 9 ).

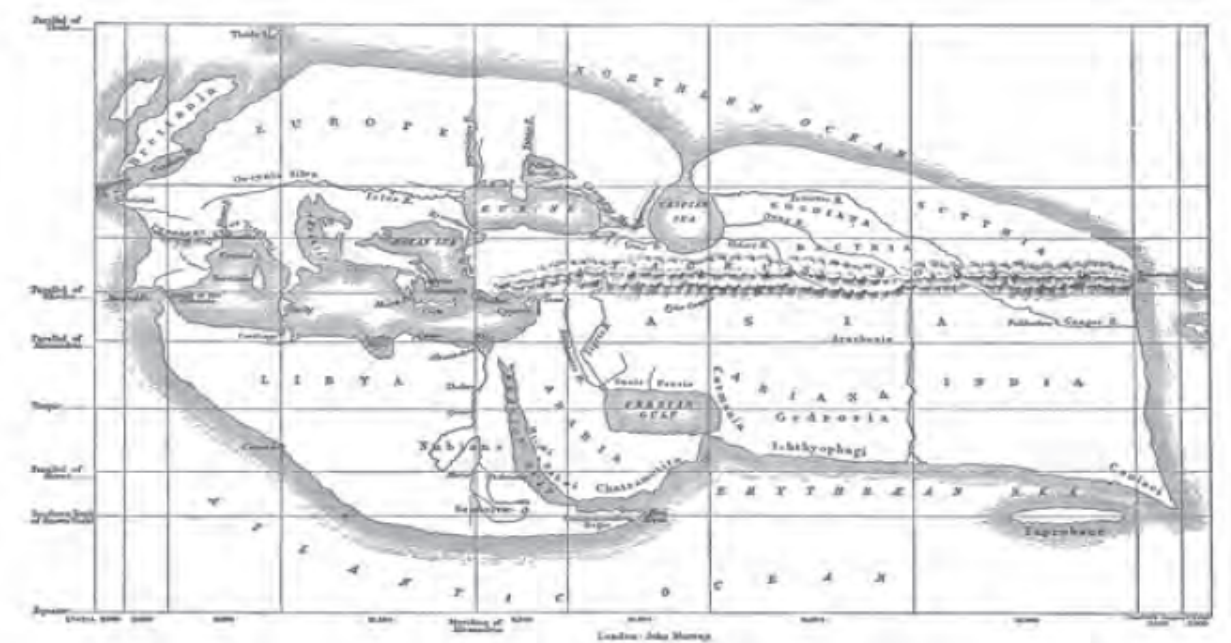

Görsel 1.6: Erotesthenes'in dünya haritası

Fig. 9. Single map without task or activity in a Turkish geography textbook (MoNE, 2018, p. 27)

At the same time, the fact that the measurement and evaluation question aimed at using the map skill contained in Turkish geography textbooks cannot go beyond the knowledge stage is an important element that will push the student out of his or her interest to geography (Figure 10).

20.

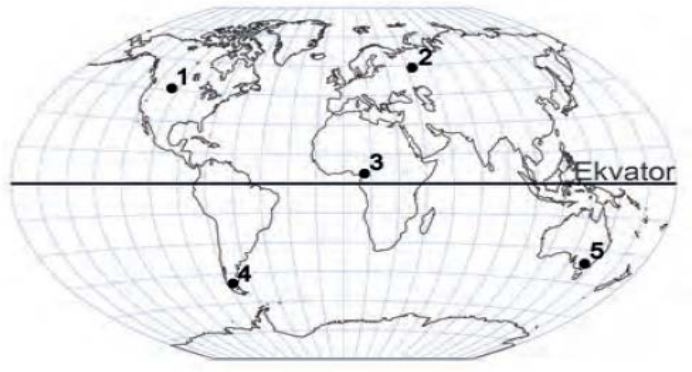

Yukarıdaki dünya haritasında verilen noktalardan hangisinde, yaşanan gündüz süresinin yıl içindeki değişimi diğerlerine göre daha azdır?
A) 1
B) 2
C) 3
D) 4
E) 5

Fig. 10. Using only a map for assessment in a Turkish textbook (MoNE, 2018, p. 47) 
The same approach can be seen in Figures 11 and 12 . Before the information step was completed, the students were asked to know the question of the upper step, such as the understanding step.

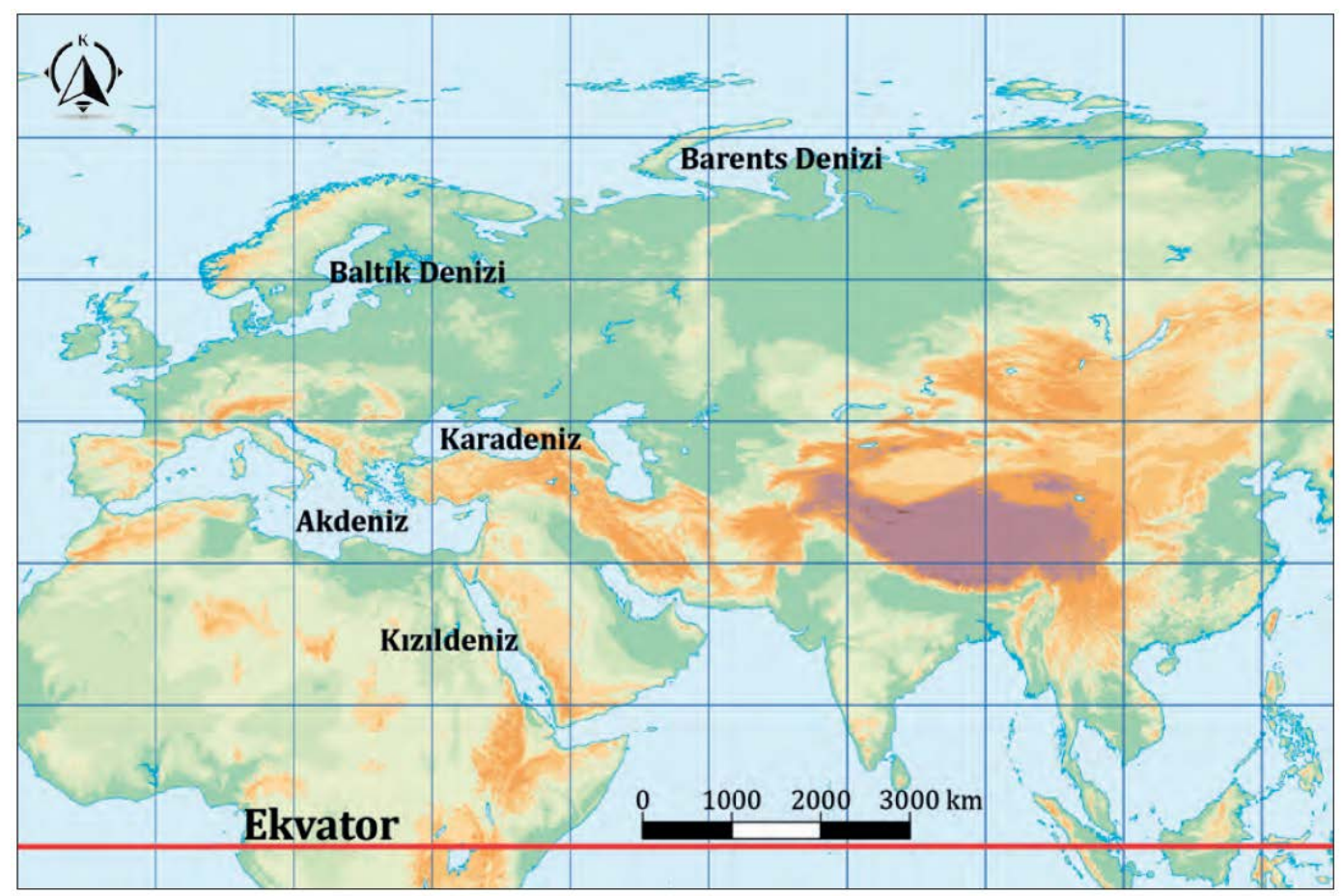

Fig. 11. Using a map without text and task interaction in a Turkish textbook (MoNE, 2018, p. 51)

\section{Ders İç Çalıșma}

Așağıda Kuzey Yarım Küre'de yer alan iki farklı ortamın 5 Ocak saat 14.30 'a ait görselleri verilmiştir.

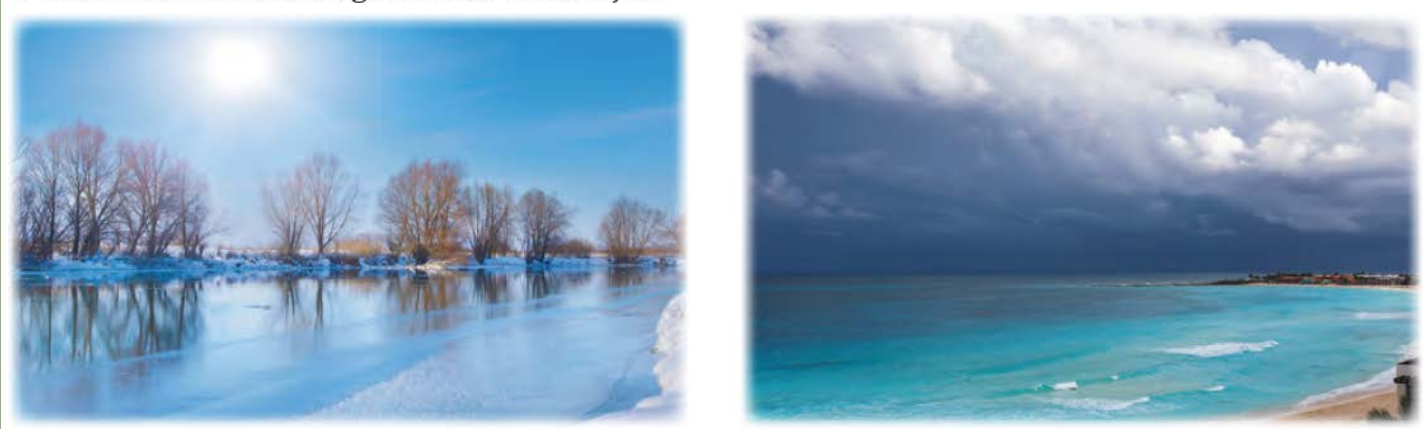

Yukarıda görselleri verilen ortamlar hangi basınç alanının etkisi altında olabilir? Hangi ortamda ayaz yaşanma ihtimali daha fazladır?

Fig. 12. A task for students without maps in a Turkish textbook

(MoNE, 2018, p. 105) 
HOW DO GEOGRAPHY TEXTBOOKS DEAL WITH MAP SKILLS? A COMPARISON ...

In the $10^{\text {th }}$ grade geography textbook, Öğrenciye harita üzerinde uygulama yapacak olanak tanınmalı ve falezlerin yaygın olduğu yerler belirtilmelidir.

In another map of a Turkish textbook, it was used a single map about cliffs, but not integrated within student tasks and real photographs of them. In addition, the formation of the cliff is not shown on the map by connecting with the coastal type. Unfortunately, the question of such an application cannot go beyond abstract conceptual knowledge for the student and become functional (Figure 13).

Falez ve Şelale

Eş yükselti eğrilerinin deniz kıyısında sıklaştığı (birbirine yaklaștığı) yerler falez oluşumlarının fazla olduğu, eş yükselti eğrilerinin akarsu vadisi boyunca sıklaştığı (birbirine yaklaștığı) yerler șelale oluşumlarının fazla olduğu alanları gösterir (Harita 1.14).

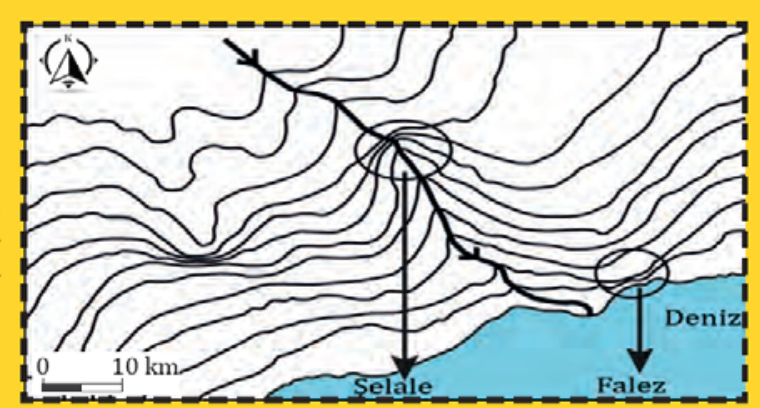

Harita 1.14: İzohips haritasında falez ve şelale gösterimi

Fig. 13. Another map in a basic level of knowledge in a Turkish textbook (MoNE, 2018, p. 82)

Some maps in Turkish texbooks are even without the basic elements of maps. For example, a map without a legend cannot develop students' map literacy (Figure 14).

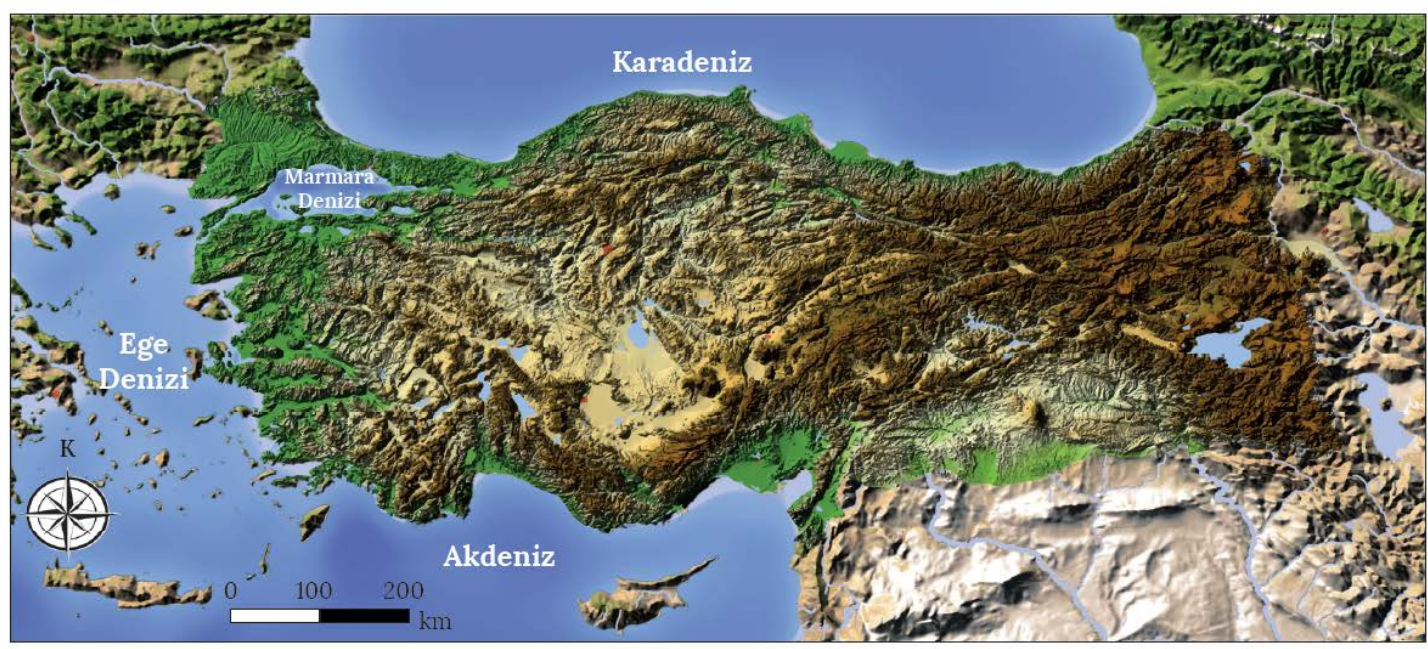

Harita 1.7: Türkiye ve yakın çevresinin bulunduğu alanın bugünkü görünümü

Fig. 14. A physical map of Turkey, without legend (MoNE, 2018, p. 38) 
It can be seen another map of Turkey without legend in Figure 15. A text together with the map is used only to give basic information to the students. There are nocritikal thingin questions of tasks or real-life matters in this part of the textbook.

Jeolojik geçmişine bakıldığında Türkiye'nin bulunduğu alan, yaklaşık 200 milyon yıl önce Tetis Denizi'nin altında yer almaktaydı. Levha hareketlerine bağlı olarak zamanla ülkemizin bulunduğu kara parçası su yüzeyine çıkmıştır. Türkiye kuzeyde Avrasya Levhası, güneyde ise Afrika ve Arabistan levhaları ile çevrilidir (Harita 1.2). Diğer levhalara göre büyük olan Avrasya Levhası, daha yavaş hareket eder. Buna karşılık Afrika Levhası'nda her yıl yaklaşık 10 mm'lik bir hareket söz konusudur. Arabistan Levhas1 da yaklaşık $20 \mathrm{~mm}$ kuzeye doğru hareket etmektedir. Bunun sonucunda arada sık1şan Anadolu Levhası'nın ise her yıl yaklaşı 20-30 mm batıya doğru hareket ettiği gö-

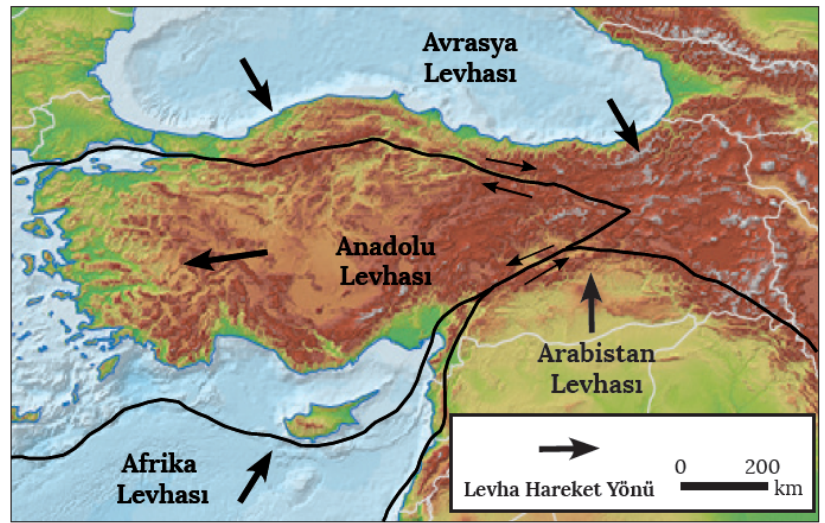

Harita 1.2: Türkiye'nin çevresinde yer alan levhalar ve bu levhalara ait hareket yönleri (Ketin İ., 1983) rülmektedir.

Fig. 15. The lack of interaction between map and ext in a Turkish textbook (MoNE, 2018, p. 22)

\section{CONCLUSI ONS AND DI SCUSSION}

In order to gain skills related to map use, various maps were used in textbooks, but activities aimed at structuring the subject were not included, especially in accordance with the constructivist approach. Some maps were also used in student workbooks, but activities were prepared in the form of questions and answers. The activities of creating maps, creating symbols, showing them on the map, interpreting maps, recognizing map types were not given much place for students to configure their knowledge about using maps. On the other hand, students should be active about not only using maps but also drawing maps. According to Bagoly-Simó et al. (2016, p. 46), based on the variety and number of challenges faced by students (e.g. form, size, position, distance, angles, etc.), school Geography should focus on including more activities to foster map drawing skills.

On the other hand, Dulamă and collaborators (2012, p. 60) state that:

"Even though teachers want to organise learning activities in which their students develop skills and competences characteristic to Geography, because of the features of the present curriculum, focusing mainly on the informative dimension of Geography (Programa şcolară de geografie pentru clasa a X-a [Geography Curriculum for the $10^{\text {th }} \mathrm{Grade}$ ]), the time resource is insufficient for teachers to focus also on the practical dimension of Geography." 
HOW DO GEOGRAPHY TEXTBOOKS DEAL WITH MAP SKILLS? A COMPARISON ...

When forming students' geographical skills, diverse variables must be taken into account (age, learning environment, and learning levels):

"It is also expressed as observational method. It is one of the inevitable applied methods in geography which has a significant role in secondary education" (Garipağaoğlu, 2001, p. 14).

"Geographical Research studies must be used in each phase of education. But the development and learning levels of students should be taken into consideration and discussed and the details about the concepts should accordingly be determined. Because field trips contain geographic activities that take place out of the classroom. Field as the lab for geography is the place for students' experimental applications. By this way students get the opportunity to use and make observations and application with their acquired knowledge during the courses" (Balcl, 2011, p. 2284).

Looking at the studies, it was concluded that the images drawn to support the map skill in the geography textbooks used in Turkey could not go beyond theoretical knowledge. The lack of work in the field also proves that there is no focus on solving the problem, and that it continues with the traditional style of learning and teaching. However, the opportunities offered to us by today's developing technology enable us to develop the map skills of QR code application contained in our textbooks. Looking at geography textbooks in the United Kingdom, they were found to be both theoretical, functional, current, and practical.

According to the results of this study, some suggestions can be offered so that Turkish geography textbooks develop students' map skills:

- Another study can be done on whether the map skills development program has an impact on different skills such as critical thinking, creative thinking, problem solving on students.

- The basis of the map skills that are the subject of research should be acquired in previous training levels. In order to gain these skills, it is necessary to increase the visualness and use of maps, and to participate in practical skills acquisition.

- Appropriate steps and explanations should be included to guide geography teachers in the acquisition and transfer of map skills included in the secondary education program by teachers to students. Again, guide activity books that teachers will benefit from when transferring these skills should be printed.

- A book that wants to improve map skills should first reconsider the maps in its contents.

- Maps that are suitable for their purpose should be converted into a concept associated with other diagrams around them, allowing map literacy to develop.

- The map that should be highlighted for students when acquiring directional skills is a map of where they live. This is why maps must be closely spaced to be viable.

- Maps to be drawn into textbooks should allow field work for students. Tasks should be given about fiedwork to students and there should be an approach in textbooks to apply these tasks in the field for students. 


\section{EYÜP ARTVİNLİ, LEYLA DÖNMEZ}

- Teaching the use of maps should be done in a way that is based on the close environment of students, as it is thought that it will attract more attention.

- Individuals encounter in daily life maps and road maps for their travels up to read, travel and textbooks and student workbooks to provide students a better understanding of the places they see in everyday life, for use in the navigation activities will location on map, roadmap activities often must be used.

- In textbooks and student workbooks, maps and aerial photographs prepared with Geographic Information Systems (GIS) should be more included. Applications that will be downloaded to smart boards should also include elements that will support map skills.

\section{References}

Abbak, A. C. (2016). Social Studies Course Examination of Map Reading and Interpretation Skills According to Teacher and Student Opinions. (Unpublished Master's Thesis). Adana: Çukurova University, Institute of Social Sciences.

Ablak, S., Aksoy, B. (2018). Investigation of student perceptions related to spatial perception skills in social studies program. Turkish Studies Educational Sciences, 13/11, 1-32, http://dx.doi.org/10.7827/TurkishStudies.13234

Aksoy, B. (2019). Determination of Map Literacy of Undergraduate Geography Students. Review of International Geographical Education Online (RIGEO), 9(3), 591-603. Retrieved from http://www.rigeo.org/vol9no3/Number3Winter/RIGEO-V9-N3-6.pdf, DOI: $10.33403 /$ rigeo. 582301

Aksoy, B., Ablak, S. (2019). An Evaluation of Map Literacy of Social Studies Preservice Teachers, Participatory Educational Research (PER) Vol. 6(2), pp. 158-168, http://dx.doi.org/10.17275/per.19.19.6.2

Aksoy, H. (2012). Effect of Applications to Gain Map Skills in Geography Courses on the Attitudes of Teachers and Students. (Unpublished Master's Thesis). İstanbul: Marmara University, Institute of Educational Sciences.

Artvinli, E. (2009). Level of Access to the Skills Predicted by the Geography Program in the Ninth-Grade Textbooks. Erzincan University Journal of Education Faculty, 11(2), 51-66.

Artvinli, E. (2010). Structuring Geography Courses: A Course Design Based on Action (Action) Research. Marmara Geography Journal, 21, 184-218.

Bagoly-Simó, P., Dulamă, M.E., Ilovan, O.-R., Kosinszki, S.-A., \& Răcășan, B.S. (2016). Exploring Map Drawing Skills of Geography Teacher Training Students. In Chiş, V. \& Albulescu, I. (eds.), $4^{\text {th }}$ International Conference "Education, Reflection, Development," pp. 41-47.

Bahar, H.H., Sayar, K., \& Başıbüyük, A. (2010). Examination of Sketch Reading Skills of Primary School Students (Erzincan Example). Firat University Journal of Social Sciences, 20(1), 229-246. 
HOW DO GEOGRAPHY TEXTBOOKS DEAL WITH MAP SKILLS? A COMPARISON ...

Balcı, A. (2011). The Effect of Discussion Supported Geographical Research Trips on Academic Achievement. Scientific Research and Essays, 6(11), 2274-2285.

Balcı, A. (2015). A Study Aimed at Determining Map Literacy in Geographical Land Applications of Geography Teacher Candidates. Journal of Academic Social Research, 10, 16-35.

Bednarz, S.W.; Betis, N.; Boehm, R.; Sauza, A.; Downs, R.; Marran, J.; Morril, R.; Salter, C. (1994). Geography for Life: National Geography Standards. Washington D.C.: National Geographic Society. 11. 09. 2020. Retrieved from https://files.eric.ed.gov/fulltext/ED375073.pdf

Cambers, G. \& Sibley, S. (2010). Cambridge IGCSE Geography Coursebook. Cambridge: Cambridge University Press.

Cendek, M.E. (2015). Opinions of Social Studies Teachers on the Development of Map Literacy in Students. (Unpublished Master's Thesis). İstanbul: Marmara University, Institute of Educational Sciences.

Dulamă, M.E. \& Ilovan, O.-R. (2016). How Powerful is Feedforward in University Education? A Case Study in Romanian Geographical Education on Increasing Learning Efficiency. Educational Sciences: Theory \& Practice (ESTP), Kuram ve Uygulamada Eğitim Bilimleri (KUYEB), 16(3), 827-848. DOI: 10.12738/estp.2016.3.0392

Dulamă, M.E. (2014). The Use of Geographic Thematic Maps in E-Learning. Exemplification: Bobota Village, Romania. In Vlada, M., Albeanu, G., \& Popovici, D.M. (eds.), Proceedings of the $9^{\text {th }}$ International Conference on Virtual Learning (pp. 52-59). București: Editura Universității.

Dulamă, M.E., Ilovan, O.-R., \& Niţoaia, A. (2016). Forming and Assessing the Competence to Elaborate Proposals of Spatial Planning Measures for Hydrographical Basins. PedActa, 6(1), 16-27.

Dulamă, M.E., Ilovan, O.-R., Conţiu, A., \& Conţiu, H.-V. (2012). Representing Urban Space According to the Features of the Ideal City. Romanian Review of Geographical Education, 1, 43-61.

Duman, B. \& Girgin, M. (2007). Faculty of Education Students' Views on Map Literacy. Eastern Geography Journal, 12(17), 185-202.

Ertuğrul, Z. (2008). Primary 6. Determination of Map and Sphere Usage Skills of Class Students. (Unpublished Master's Thesis). Ankara: Gazi University, Institute of Educational Sciences.

Garipağaoğlu, N. (2001). The Place of Excursion - Observation Method in Geography Education and Teaching. Marmara Geography Journal, 4, 13-30.

Gersmehl, C. (1995). Using Maps in Classrooms. In Kembal, W. (ed.), Spaces and Places: A Geography Manual for Teachers (pp. 79-93). Published by the Geographic Education National Implementation Project (GENiP) with the cooperation of Rand McNally \& Company. 25 March 2020. Retrieved 15 June 2020, from https://files.eric.ed.gov/fulltext/ED418040.pdf

Güneş, G. (2016). Social Studies Teacher Candidates' Ability to Use Maps and Map Symbols in Geography Subjects. (Unpublished Master's Thesis). Kırşehir: Ahi Evran University, Institute of Educational Sciences.

Harte, J. \& Dunbar C. (1994). Skills in Geography. Cambridge: Cambridge University Press. 


\section{EYÜP ARTVİNLİ, LEYLA DÖNMEZ}

Kartal, F. (2016). Examination of Map Literacy Levels of Secondary Education Students in Terms of Various Variables. (Unpublished Master's Thesis). Sivas: Cumhuriyet University, Institute of Educational Sciences.

Kızılçaoğlu, A. (2007). A Pedagogical Look at Map Skills. Selcuk University Journal of Institute of Social Sciences, 18, 341-358.

Koç, H. (2008). Effect of Gains in Geography Curriculum on Students' Map Skill Levels. (Unpublished Doctoral Thesis). Ankara: Gazi University, Institute of Educational Sciences.

Kuzey, M. (2016). A Review on Map and Direction Literacy of Secondary School Students. (Unpublished Doctoral Thesis). Erzurum: Ataturk University, Institute of Educational Sciences.

Manzella, K. (2007). A View from Above: A Map Skill Unit. (Unpublished Master's Thesis). New York: Hof stra University.

Meriç, A. (2011). Spatial Cognition and Map Reading Skills of Students Studying Social Studies and Preschool Teaching. (Unpublished Master's Thesis). Aydın: Adnan Menderes University, Institute of Social Studies.

Ministry of National Education (MoNE) (2018). 10. Sınıf Coğrafya Ders Kitabı. Ministry of National Education, Ankara.

Naylor, D.T. \& Diem, R. (2001). Elementary and Middle School Social Studies (3 ${ }^{\text {rd }}$ ed.). New York: McGraw-Hill Higher Education.

Osaci-Costache, G., Dulamă, M.E., Alexandru, D., \& Voitovici, M.-R. (2013). Forming and Assessing the Competence to Elaborate Touristic Plans. PedActa, 3(2), 97-114.

Özcan, F. (2015). Map Reading Recursion and Success Levels of Social Studies Teacher Candidates. (Unpublished Master's Thesis). Aksaray: Aksaray University, Institute of Social Sciences.

Patton, M.Q. (2015). Qualitative Research \& Evaluation Methods: Integrating Theory and Practice. Fourth edition. CA: Sage Publications.

Petty, M.R. \& Rule, A.C. (2008). Effective Materials for Increasing Young Children Spatial and Mapping Skills. Journal of Geosciences Education, 56(1), 5-14.

Şahin, C. (2001). A Study of the Professional Problems of Secondary Geography Teachers. Marmara Geography Journal, 4, 60-70.

Sönmez, Ö. \& Aksoy, B. (2013). Map Skills and Present of Republic Elementary School Curricula. Türkiye Sosyal Araştırmalar Dergisi, 171, 269-288. Retrieved 11 June 2020, from https://dergipark.org.tr/tr/pub/tsadergisi/issue/21497/230500

Sönmez, Ö.F. \& Aksoy, B. (2012). Determination of Primary Education Secondary Stage Students' Map Skill Levels. Turkish Studies - International Periodical for the Languages, Literature and History of Turkish or Turkic, 7(1), 1905-1924.

Sönmez, Ö.F. (2010). Map Skills in Elementary Social Studies Teaching. (Unpublished Doctoral Thesis). Ankara: Gazi University, Institute of Educational Sciences.

Strauss, A. \& Corbin, J. (2008). Basics of Qualitative Research: Techniques and Procedures for Developing Grounded Theory. London: Sage. 
HOW DO GEOGRAPHY TEXTBOOKS DEAL WITH MAP SKILLS? A COMPARISON ...

Umek, M. (2003). A Comparison of the Effectiveness of Drawing Maps and Reading Maps in Beginning Map Teaching. International Research in Geographical and Environmental Education, 12(1), 18-31.

Ünlü, M., Üçışık, S., \& Özey, R. (2002). The Importance of Maps in Geography Education. Marmara Geography Journal, 5, 9-25.

Üzümcü, O. N. (2007). Obtaining Map Reading Skills by Active Learning Method in Primary School Sixth Grade Social Studies Course (Unpublished Master's Thesis). Ankara: Gazi University, Institute of Educational Sciences.

Wach, E. (2013). Learning about Qualitative Document Analysis. Retrieved 27 May 2020, from https://opendocs.ids.ac.uk/opendocs/bitstream/handle/20.500.12413/2989/ PP\%20InBrief\%2013\%20QDA\%20F INAL2.pdf ?sequence $=4$.

Wachter, C.A. (2010). Understanding and Responding to Concerns Related to Giftedness: A Study of CACREP-accredited Programs. Journal for Education of the Gifted, 33, 390-393.

Yıldırım, A. \& Şimşek, H. (2016). Qualitative Research Methods in the Social Sciences (Expanded 10. Printing). Ankara: Seçkin Publishing.

Yurdam, A. H. (2013). GIS for Process-based Geography Courses: An Action Research Based on Student Effectiveness. (Unpublished Master's Thesis). İzmir: Aegean University, Institute of Social Sciences. 